IBIMA Publishing

Journal of Financial Studies \& Research

http://www.ibimapublishing.com/journals/JFSR/jfsr.html

Vol. 2016 (2016), Article ID459564, 9 pages

DOI: $10.5171 / 2016.459564$

Research Article

\title{
The Relationship between CDS Market and Public Debt Market
}

\author{
Souhir Amri Amamou and Sleheddine Hellara
}

The Higher Institute of Management of Tunis, Tunisia

Correspondence should be addressed to: Souhir Amri Amamou; amri_souhir11@yahoo.fr

Received date: 21 March 2016; Accepted date: 22 August 2016; Published date: 30 December 2016

Academic Editor: Besma Hkiri

Copyright (C) 2016. Souhir Amri Amamou and Sleheddine Hellara. Distributed under Creative Commons CC-BY 4.0

\begin{abstract}
Credit default swaps (CDS) are very recent diversified products in global markets whose analysis has attracted the interest of researchers since their appearance and intensified following the subprime crisis in 2008. These products, whose marketing was really fast and easy, have become one of the largest credit derivatives markets but also one of the most criticized. The purpose of this work is to answer the question: What is the impact of CDS on the cost of the public debt: case of the Euro zone? To answer this question, we will seek to identify the role of these products in crisis via the analysis of the literature review and we will verify our theoretical results by an empirical approach on the sovereign debt market relative to the Euro zone crisis.
\end{abstract}

Keywords: credit default market, sovereign, public debt

\section{Introduction}

Increased risks threatening the financial system prompted the emergence of several hedging products. This work focuses on one of these products, namely the market of credit default swaps (CDS) .It's a contract under which a protection seller agrees, in return of a premium called spread, to compensate the buyer in case of credit events affecting the creditworthiness of a reference entity.

CDS can be an alarm means against any disruption in the market debt. Moreover, according to Ismailescu \& Kazemi (2010), in a study conducted about the conditions of emerging markets, the use of CDS spreads help market participants to predict adverse change in quality of credit. So the CDS may be both a means of influence and reflection of the debt market conditions.

However, the determination of the sign and the nature of the relationship between the two markets is a fairly complex task. Some consider that the CDS promote confidence in the financial system and they promote market stability (Geithner (2006) and Greenspan (2005)) by allowing the transfer of risk which could create a source of disturbance. Since, they reduce the concentration of individual exposures of banks as they promote credit risk more widely distributed to those parties.

Cite this Article as: Souhir Amri Amamou, Sleheddine Hellara(2016), "The Relationship between CDS Market and Public Debt Market", Journal of Financial Studies \& Research , Vol.2016 (2016),

Article ID 469564 DOI: $10.5171 / 2016.469564$ 
This is a highly questionable viewpoint, since other researchers show that the low transparency of CDS amplified the distrust phenomena and uncertainty about the global exposure and recovery of key financial stakeholders' products (as Brown (2010)). In this case a new hypothesis is supported by the literature considering that CDS are not in any way stabilizers but disruptive of the financial market. The only explanation for this discrepancy is the difference between studies in terms of countries and period.

An analysis of the literature on the relationship CDS / interest rates of debt leads us to two types of relationships either a negative or a positive relationship. In the case of a positive relation, interest rates positively follow any trend in CDS so they increase following the increase in the use of CDS and vice versa. This result was supported in the literature by several researchers among which we mention: Hirtle (2008), Minton \& al (2006), Naifer (2008), Norden \& Wagner (2008) and others.

In contrast, if we are faced with a negative relationship, an additional demand of protection via CDS may reduce the cost of debt. This hypothesis has been supported by some studies as Aschcraft \& Santos (2009) and Ken Ho Yu, Yu Yen Hsio \& Lo Wen-Chi (2010).

Whatever the sign of the relationship, we can confirm the existence of arbitrage relations between CDS spreads and credit spreads by the work of Duffie (1999) and Hull \& White (2000). This relationship is linked to enormous difficulties in fixation of its sign. That's why researchers have not agreed on this point by presenting different results.

We should note that the crisis has affected all financial markets especially markets of debt and CDS market. So, it remains to analyze whether the CDS slow levels of interest rates evolution in crisis or they aggravate the situation in the sovereign debt market by procuring higher rates.

Our work starts with the detection of the theoretical relationship between sovereign CDS and the cost of the debt in crisis time essentially sovereign crisis in the euro area. Thereafter, we will move to empirical verification by presenting our methodology consisting on the estimation of a model which tries to identify the sign of the relationship between spreads of CDS and yield to maturity sovereign bond spreads in euro area, taking into account other macroeconomic variables included in auxiliary models. The choice of these control variables is supported by recent studies such as Gauthier \& Lardic (2003), Norden \& Wagner (2008) and Fontana \& Scheicher (2016). Finally, we will present our results. Discussion and conclusion of these results will complete this work.

\section{Review of the literature}

Typically, CDS significantly facilitate the marketing of credit risk when financing costs are low, which allows market participants to overcome short credit risks as easily as long credit risks (Longstaff, Mithal, \& Neis, 2005) . This remains true in an environment characterized by low interest rates thus a stability framework. Except that during the crisis, the cost of financing increases by reducing or eliminating the return of arbitrageurs (Fontana, 2010).

Knowing that following the use of CDS, strong dependencies seem to exist between the entities. If this use is associated with the crisis framework already characterized by multiplicity of bankruptcies, the risk of deterioration in credit quality will be much stronger and the impact of CDS on the debt market will be more intense. It will focus specifically on interest rate levels. This result is confirmed by the literature as Cont (2010) which argues that these products were accused by effecting financial stability in times of crisis.

To the best of our knowledge, there are few empirical studies on the relationship between CDS market and cost of public bond debt for developed countries in the Euro zone in crisis, which explains the complexity of decision making about the exact sign of this relation.

Our study will turn around the detection of sovereign CDS's role on sovereign crisis in order to detect by the following empirical 
study the nature (stabilizer or destabilize) of CDS on the financial sector in times of stress.

The sovereign crisis is basically a public debt crisis due to an excessive increase in government spending on social assistance, unemployment ... . .These expenses are associated with little or no wealthproducing destinations at the expense of investments which have been neglected by government big social pressure.

This excess of indebtedness has affected governments specially in difficult situations mainly due to the financial crisis of 2008 . Financial System support actions associated with economic recession and unfavorable conditions for investment have compounded the situation of indebted countries.

The easiest solution for these countries was to increase their public debt to find the necessary financial means for such acts of regulation, which favored a phenomenon of government debt snowball. Besides, it is in countries whose public finances were already precarious that the debt has increased faster (Boone \& al (2010)). However, this required an increase in these markets' coverage premiums.

The first signals of the sovereign crisis were felt following the announcement of record government deficits in the euro area which was accompanied by a movement of panic and a harsher view of risk levels of public debt markets.

The general perception of sovereign debt has been challenged by researchers and stakeholders in the financial market especially that this type of investment was considered as the safest.

An idea which has been proved quite far from the reality essentially on euro area where the government budget deficit bounded by a high level debt countries pushed the financial system to a very complicated situation.

The periodic phase of this major government problem made the situation worser. A phase in which the states have been forced to support their monetary systems (banks) by acting as guarantor or even trying to support them in their fight for survival by seeking capital resources. However, despite the very advanced government efforts in terms of regulation of the public debt crisis, the situation remains precarious mainly affecting the euro area which attracted the interest of several researchers and stakeholders in the financial market.

Besides, according to Dieckmann \& Plank(2011) government interventions have been associated with a transfer of risk from private to public sector which is more important for the euro area than other countries.

This transfer associated with predictable shock can generate a contagion process. Taback \& al (2016) defined contagion as an increase of correlation across countries in crisis times. So, an increase of a market's prices is necessarily associated with an increase of prices in correlated market which can promote transmission of a shock between markets (Dungrey \& al (2004)).

Hsiao \& Morley (2015) considered that euro area sovereign crisis was more predictable than subprime crisis which can explain the emergence of sovereign CDS market due to research of security by market stakeholders in sovereign crisis. According to Olléan-Assouan (2004), sovereign CDS was created in order to cover a predictable country risk.

Despite these products form a relatively small market compared to bond, many research studies consider the CDS market fully reflects the market situation. Moreover, they consider that it is able to give advance signals to default incident. So, spreads of CDS could be used as a tool for testing contagion since they serve as a proxy of market default probabilities (Kalbaska \&and Gatkowski (2012)).

Researchers have long believed that there is no difference between CDS spreads and those of sovereign bond yields. Besides, Duffie (1999) with Hull \& White (2000) found a parity relationship between bond spreads and CDS spreads in the absence of arbitrage opportunity. Yet, others believe that there exist differences between the 
two spreads such as: Dellate \& al (2011), Mithal, \& Neis (2003)....

Theoretically, this topic is now a center of debate especially with recent economic trends. Besides, several researchers analyzed the existence and the sign of the relationship between CDS spreads and those of the bond debt. Hull, Prescu \&and white (2004) demonstrate that this relationship exists. Even the finding of Dellate \& al (2011) insisted that bond and CDS contact must be within the same entities of similar maturities.

In the same subject, Giovanni Calice \& al (2011) found that it is possible to consider the existence of a causal relationship between the increase in bond spreads and CDS to countries heavily affected by the crisis (like: Greece, Portugal and Ireland) .This point of view has been supported by Norden \& Weber (2004), Blanco \& al (2005), Zhu (2006) and Baba \& Inoda (2007) who believed that innovations in the CDS market affect more severely bond spreads than the reverse.

A confirmation supported by the work of Coudert \& Gex (2010) who believe that the CDS market is ahead of the bond market even out periods for the decline (excluding crisis) . Similarly, Blanco \& al (2005) believed that price discovery process is made on the CDS market.

Nothing that sovereign CDS are still far from being quite competitive with corporate CDS. This is due to the size of this market which is still very limited because of the general perception of the level of risk that governments considered non-existent or very low. This view of the risk explains big differences between the volume of public debt protected via sovereign CDS and the total sovereign debt market; in contrary, the CDS corporate market is larger than the debt market to which it is assigned by the contracts' accumulation phenomenon.

The exchange impact of sovereign CDS on changes in the cost of debt has begun to attract the importance and the interest of researchers with the development of the volumes of transactions in these markets.
Most previous studies on this topic (Blanco, Brennan \& Marsh (2005) ...) have shown that CDS spreads influence credit spreads. In this case, it is very interesting to see if the effect caused by this type of engagement is positive or negative on the debt market particularly in times of crisis already characterized by increasing levels of risk and of failure fears.

The current phase, namely that of a sovereign crisis in the euro area, encourages us more to test the relationship between CDS spread and spread sovereign bond yields in the euro area.

The detection of the sign of this relationship will be really helpful for explaining the influence of CDS over financial market stability and their recovery of the public debt by detecting their impact on its cost.

\section{Methodology}

Our work will focus on the euro area. This choice is explained by the period faced by the area. A period characterized by stress and enormous pressure from the public debt crisis.

The sovereign debt crisis began to gain momentum and be a concern from the beginning of 2010 which explains our choice of the study period from 22 March 2010 until 22 February 2016 in the form of daily data.

The purpose of the empirical part is to answer the question: Does the use of the CDS market negatively affect the cost of the public debt in times of stress?

To answer this question we will estimate the following linear regression model:

$\Delta$ sovereign credit $_{t}+=$ $\beta_{0}+\beta_{1} \Delta$ sovereign credit $_{t-1}+\beta_{2} \Delta C D S_{t-1}+\varepsilon_{t}$

$\Delta$ sovereign credit $_{t}=$ represents the evolution of spreads in yields of sovereign bond debt at time $\mathrm{t}$

$\Delta$ sovereign $_{\text {credit }} t-1=$ represents the evolution of spreads in yields of sovereign bond debt at time $\mathrm{t}-1$ $\Delta C D S_{t-1}=$ represents the evolution of sovereign CDS spreads at time $\mathrm{t}-1$ 
$\varepsilon_{t}=$ the error term

This is the basic model (model 1) from which we seek to understand the relationship between sovereign bond yield's spreads and those of sovereign CDS after presenting the context of the theoretical relationship between credit spreads and changes in the interest rate.
Several other auxiliary models will be introduced gradually after. First, we will look at the impact of other control variables on the spreads of sovereign bond debt starting with the variable "the harmonised Index of Consumer Prices for the euro area" and adding other variables presented in the following table one by one.

Table 1: The variables used

\begin{tabular}{|l|l|}
\hline Variable & Definition \\
\hline Sovereign credit & sovereign bond yield's spreads \\
\hline CDS & sovereign CDS spreads \\
\hline Ipch & the Harmonised Index of Consumer Prices for the euro area \\
\hline Exchange & Exchange rate : Euro/dollar \\
\hline Eurostoxx & European stock index \\
\hline & \\
\hline
\end{tabular}

Finally, we will add to the new variable "sovereign CDS spreads" to see the impact of this variable in the presence of other macroeconomic variables of the euro area market.

We start by testing the relationship between the Harmonised Index of Consumer Prices for the euro area and sovereign bond yield's spreads.

Later we will add another variable to the second model which is the evolution of the exchange rate Euro / dollar to form the third model (Model 3). Then we'll add the variable "development of a European Eurostoxx stock index" as part of a fourth model (Model 4) .This model will include all macroeconomic variables and try to seek the impact of these variables on changes in sovereign bond yield's spreads.

To better understand the impact of changes in sovereign CDS spreads on sovereign bond yield's spreads, we will add the explanatory basic variable "changes in sovereign CDS spreads" to the fourth model to form a fifth model (Model 5).

We mainly focus on two models in our analysis which are the first and the fifth model to identify the exact role of CDS alone without taking into account other variables and with consideration of macroeconomic variables .Then we will make a comparison between the two cases.

Under this section we will try to accept or reject the hypothesis that the developments in the CDS market promotes destabilization of the financial system by increasing public commitments in terms of interest rates

The interest rate of a bond follows an inverse relationship to the evolution of sovereign bond yield's spreads so it increases when it decreases and conversely decreases.

A positive relationship $\left(\beta_{2}>0\right)$ between sovereign bond yield's spreads and sovereign CDS spreads means that increments in the use of CDS market lead to increasing sovereign bond yield's spreads. These are inversely related to interest rates. In this case, an appeal to the CDS market increases in sovereign bond yields spreads and reduces the cost of public debt.

Moreover, a negative relationship $\left(\beta_{2}<0\right)$ between sovereign bond yield's spreads and sovereign CDS spreads means that increments in the use of CDS market lead to decreasing sovereign bond yield's spreads. These are inversely related to interest rates. In this case, an appeal to the CDS market decreases in sovereign bond yield's 
spreads and is accompanied by a rise in the cost of public debt

We can conclude then that if $\left(\beta_{2}<0\right)$ we accept $\mathrm{H}$

reject $\mathrm{H}$

\section{Results and discussion}

After testing variables we found that only the variable sovereign credit is stationary at level. For other variables, they are stationary in first difference.

Table 2: Representative table of the OLS estimate results related to the basic model and its extensions

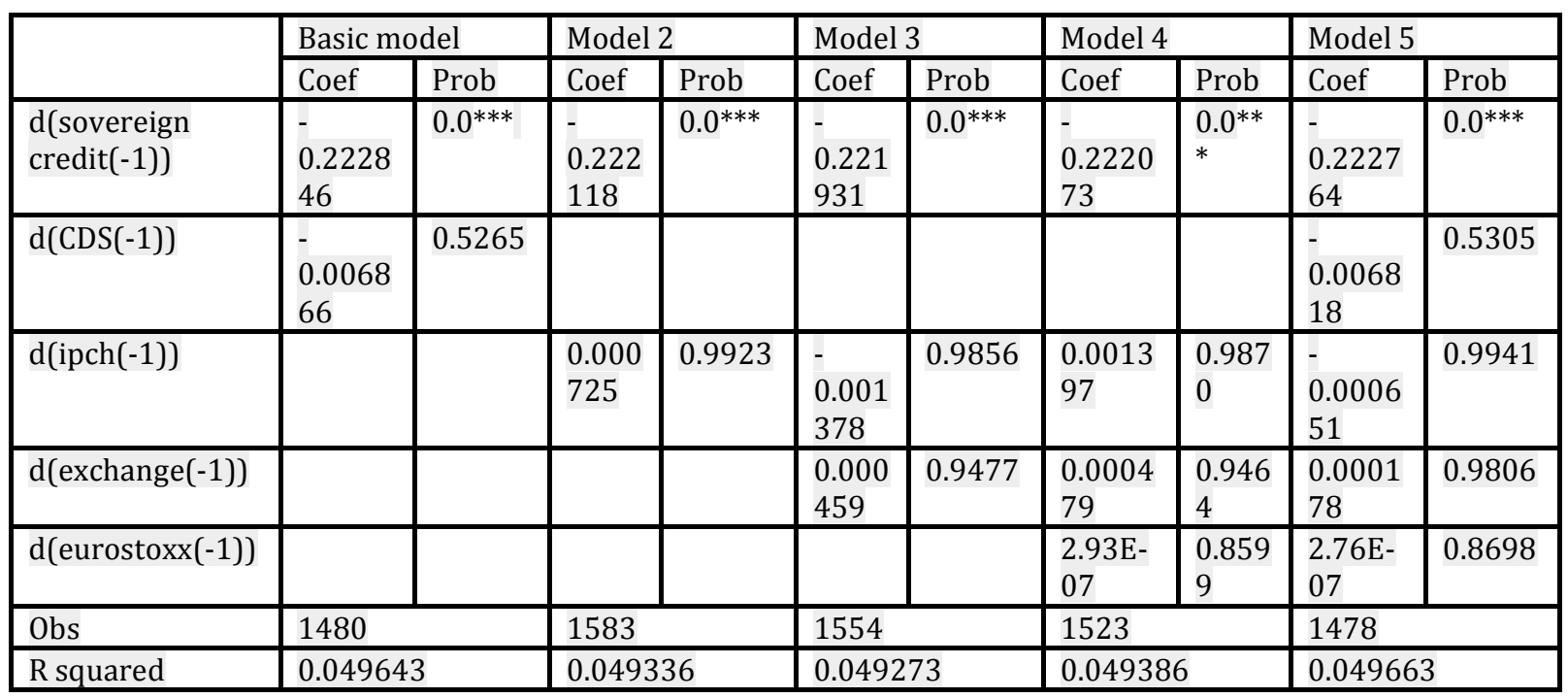

*: Significant at $10 \%$

** Significant at 5\%

*** Significant at $1 \%$

\section{For the basic model}

The variable $\Delta$ Sovereign credit $_{t-1}$ has a negative effect significant at about 1\% against the variable $\Delta C D S_{t-1}$ which has a negative but insignificant effect.

For Model 5 (Extension with consideration of CDS variable):

Only $\Delta$ sovereign credit $_{t-1}$ is significant to the order respectively $1 \%$.For other variables, $\Delta C D S_{t-1}$ and $\Delta I p c h_{t-1}$ have both a negative and insignificant effect unlike $\Delta$ Eurostox $_{t-1}$ and $\Delta$ Exchange $_{t-1}$ which have a positive effect.

Applying the white test, we found that the probability is equal to 0.0000 which is well below 0.05, so mistakes are heteroscedastic. Correlation perspective, the Durbin Watson indicates a value of
1.988519. This result means that there are no errors of autocorrelation.

For the analysis of errors' normality, the coefficient of the asymmetry's distribution degree (skewness) is equal to -14.97527 .The distribution shifted to the right of the middle, and therefore a wide distribution of tail left.

Kurtosis measure the degree of distribution crushing. It's equal to 432.9578. In our case, the distribution is leptokurtic . As to probability associated with the test Jarque Bera (0.00000), it is less than 0.05 which means that there is no normality of errors. A comparison between the basic model \& the extension of the model taking into account the variable CDS brings us back to the results presented in the table below. 
Table 3: Comparative table

\begin{tabular}{|c|c|c|}
\hline & Basic model & $\begin{array}{l}\text { Model with extension } \\
\text { (model 5) }\end{array}$ \\
\hline$\beta_{2}$ & -0.006866 & -0.006818 \\
\hline R squared & 0.049643 & 0.049663 \\
\hline
\end{tabular}

The coefficient of changes in sovereign CDS spreads $\beta_{2}$ is negative. In this case, the hypothesis is accepted in the basic and in extension model. So, there is a negative relationship between changes in sovereign bond yield's spreads and those of sovereign CDS.

This result means that an increase in sovereign CDS spreads (thus increasing the cost of protection via CDS) reduced the spreads of sovereign bond yield's spreads. The prices of sovereign CDS rise with the increase in demand of these instruments on the market and following the law of supply and demand. Therefore, the use of CDS (expressed by the increase in demand) increases the prices of these and increases the interest rates on sovereign debt market.

The non-significance of the results can be explained by the huge difference in terms of size between public bond debt market and sovereign CDS market which remains an emerging market and therefore of small size compared to the public debt market developed enough especially following the subprime crisis.

Comparing the two models, we note that the quality of fit improves with consideration of other macroeconomic variables. As for the relations of these with developments in spreads of sovereign bond debt, they will be analyzed in the following table.

Table 4: Summary table

\begin{tabular}{|l|l|l|}
\hline Variables & Expected signs & OLS results \\
\hline EUROSTOXX & + & + \\
\hline CHANGE & + & + \\
\hline IPCH & - & - \\
\hline
\end{tabular}

The emergence of CDS market is explained by the increase of protection demand by associated with an increase in premiums. This phenomenon was unveiled following the subprime crisis on 2008 and has increased with the countries deficits declaration following a huge level of public debt.

For sovereign CDS, their market was very limited until 2010. Since, demand for protection increased providing market growth. It can be explained by the new perception of the real public risk in the euro area which was really undervalued before sovereign crisis.
The increase of market risk levels is associated with a more demand of protection from buyers of government bonds which will be stricter for required returns .They require superior performance to agree to support a new level of risk they feel superior. These new requirements are reflected mainly on bonds interest rate levels. Moreover, the new remuneration must be greater in parallel to risk increased which will weigh on bond issuers' states and therefore constitute an additional burden on those countries that are already in serious debt crisis.

Sovereign CDS therefore contributed to pushing the deficit countries in the euro 
area and to hiding the true facet of market risk. The effect crisis has disclosed the true risk coverage provided by this tool. It has helped to change general perceptions vis-àvis this instrument.

\section{Conclusion}

We can therefore conclude that the CDS have not played the expected role in crisis. Instead, they have presented a source of destabilization since the expansion of their market led to an increase in costs in terms of interest for sovereign bonds.

The properties of this product have created fertile ground for the emergence of the crisis and provided negative effects on the public indebtedness situation especially on the euro zone.

Our study contributes that CDS, normally able to reduce the deficit of a country by improving stability of bond market and mitigating the costs of their debts, provoked the growth of countries deficits.

CDS inefficiency was proved particularly in terms of information. Poor quality of information favored by this market had strongly affected their contribution and therefore the general perception of their real risk. Besides, destabilization favored by CDS is explained by the scarcity of information reflected by this market because of its opacity.

In this regard, Longstaff \& al (2005) consider that spreads of CDS provide a sufficient measure of market default. However, this measure needs to be revised in future studies to better estimate market risk.

\section{References}

1 Ashcraft, A.B\& Joao A.C. Santos (2009): "Has the CDS market lowered the cost of corporate debt?", Journal of Monetary Economics, 56, Page514-523

2 Baba, N \& Inada, M (2007): "Price discovery of credit spreads for Japanese mega-banks subordinated bond and CDS", Institute for monetary and economic studies, bank of Japan, discussion paper
3 Blanco,R, S.Brennan \& Marsh(2005): “ An empirical analysis of the dynamic relationship between investment grade bonds and the credit default swaps", journal of finance, Pages2255-2281

4 Boone,L \& als(2010): “Dette publique et interactions avec le marché des dérivés: le cas européen" ", Banque de France, Revue de la stabilité financière $\mathrm{N}^{\circ} 14$, Produits dérivés, Innovation financière et stabilité, Juillet 2010, Pages21-29

5 Brown, O.W (2010): "Crédit default swaps : Quels risques et défis en matière de stabilité financière? ", Banque de France, Revue de la stabilité financière $N^{\circ} 14$, Produits dérivés, Innovation financière et stabilité, Juillet 2010, Pages157-163

6 Cont, R (2010) : “ Credit default swaps et stabilité financière", Banque de France, Revue de la stabilité financière $N^{\circ} 14$, Produits dérivés, Innovation financière et stabilité. Juillet 2010, Pages41-51

7 Coudert,V\& M.Gex(2010): “ Le marché des CDS et marché obligataire: qui dirige l'autre?",Banque de France, Revue de la stabilité financière $\mathrm{N}^{\circ} 14$, Produits dérivés, Innovation financière et stabilité, Juillet 2010, Pages183-189

8 Delatte,A \& als (2011): "Has the CDS market influenced the borrowing cost of europeen countries during the sovereign crises?", Journal of international money and finance, pages 481-497

9 Duffie, D (1999): “Credit default valuation", Financial analysts journal, Pages 73-87

10 Duffie, D \& K. Singleton (1999): "Modelling Term Structures of defaultable bonds", Review of financial studies, Pages 687-720

11 Fontana, A (2010): "The persistent negative CDS-Bond basis during 2007/2008 financial crisis", Working Papers, Department of Economics Ca Foscari University of Venice

12 Fontana, A \& M.Scheicher(2016): “An analysis of euro area sovereign CDS and their relation with government bonds", 
Journal of banking and finance, pages 126140

13 Gauthier,C \& S.Lardic(2003): “Un modèle multifactoriel des spreads de crédit: estimation sur panels complets et incomplets", revue économie et Prévision, 2003, vol. 159, issue 3, pages 53-69

14 Geithner, T.F (2006): "Implications of growth in credit derivatives for financial stability", Remarks at the New York university stern school of business third credit risk conference .New York city, May16, 2006

15 Giovanni, C \& als(2011): "liquidity spillovers in sovereign bond and CDS markets: An analysis of Eurozone sovereign debt crisis", SSRN Electronic journal

16 Greenspan, A (2005): "Risk transfer and financial stability".Remarks at the federal reserve bank of Chicago's forty-first annual conference bank structure. Chicago, IL, May5, 2005

17 Hirtle, B (2008): “Credit derivatives and bank credit supply", Journal of Financial Intermediation, Vol 18, Pages125-150

18 Hull, J, Predescu, M \& A.White(2004) : "The relationship between credit default swap spreads, bond yields and credit rating announcement ", Journal of banking and finance, Pages 2789-2811

19 Hull, J \& A.White(2000) : "Valuing credit default swap I:No countreparty default risk", Journal of derivatives, Vol 8(1), Pages 29-40

20 Ismailescu, L \& H. Kazemi (2010): "The reaction of emerging market credit default swaps spreads to sovereign credit rating changes", Journal of Banking and Finance, Vol 34, Pages 2861-2873

21 Ken Ho-Yu, Yen Yu Hsio \& Lo Wen-Chi (2010): "Determinants of credit default swap spread: la preuve en provenance du Japon", Journal of Economic literature

22 Longsatff, F ., S. Mithal \& E. Neis (2005): "Corporate yield spreads :default risk on liquidity? New evidence from the credit-default swap markets", Journal of Finance, 60, Pages 2213-2253
23 Minton, B., R.Stulz \& R.Williamson (2006): "How much do banks use credit derivatives to reduce risk?", Fisher College of business, Working paper $\mathrm{N}^{\circ}$ 2006-03001

24 Mithal \& et Neis(2003): "Corporate yield spreads: Default risk or liquidity? New evidence from credit default swap market", NBER working paper series

25 Naifar, N(2008): "Does the recent financial crisis affect credit default swap markets?", MPRA: Munich Personal REPEC Archive $\quad \mathrm{N}^{\circ} 11909$. Posted 03.December 2008/14:43

26 Norden, L \& W. Wagner (2008): “Credit derivatives and loan pricing", Journal of Banking and Finance, 32, Pages 2560-2569

27 Norden, L \& M. Weber (2004): "the comovement of credit default swap, bond and stock markets:an empirical anlysis", CERP discussion paper 4674

28 Olléon-Assouan, E(2004): “Techniques de marché des dérivés de crédit : les swaps de défaut", Banque de France, Revue de la stabilité financière, $N^{\circ} 4$, Pages 110-114

29 Rahman, D (2009): “Are banking systems increasingly fragile? Investigating financial institutions'CDS returns extreme co-movements", Working Paper. Economix

30 Singh, M\& C, Spackman (2009): "The use (and abuse) of CDS spreads during distress" .IMF Working Paper, WP/09/62

31 Tabak \& al(2016) : "Contagion in CDS, banking and equity markets »,Economic systems, vol(40),pages :120-134

32 Zhu, H(2006): "An empirical comparison of credit default spreads between bond market and the default credit swap market", Journal of financial services research, 29, Pages 211-23

\section{Note}

The variables used: These data are collected from www.sandpindices.com sites www.investing.com, and www.globalrates.com www.stoxx.com. 